Seloka: Indonesian Language and Education Journal
UNNES (1) (2020): $184-191$
https://journal.unnes.ac.id/sju/index.php/seloka

\title{
The Realizations and Functions of Figurative Speeches in Novels Written by Prasetyo Utomo
}

\author{
Fajar Arifiyanto $^{1 \bowtie}$, Agus Nuryatin ${ }^{2}$, Mukh Doyin $^{2}$ \\ DOI: https://doi.org/10.15294/seloka.v9i2. 40442 \\ ${ }^{1}$ SMA Negeri 1 Tuntang Kabupaten Semarang, Indonesia \\ ${ }^{2}$ Universitas Negeri Semarang, Indonesia
}

\section{Article Info}

History Articles

Received:

25 March 2020

Accepted:

25 June 2020

Published:

21 August 2020

Keywords:

Analytic, Novels, figurative language, stily, function

Abstract

Utomo's novels are very related to the theme of religion and culture. The language used tends to be simple but still interesting and beautiful so research on the form and function of language style is very interesting. The purpose of this study is to describe the form and function of language style in the three Utomo novels. Data collection is done by heuristic techniques or read by repeatedly. Data analysis method used is hermeneutics. Almost all types of figurative language styles are found, but for the sake of effective exposure, only three data would be presented as examples of the form of language style and the function of language style. The three most found figurative languages are metaphor, simile, hyperbole, personification, and sinekdoke. The function of language also varies, starting from clarifying the picture, increasing the impression, shortening the narrative, and describing the character's feelings. Fulfillment of these functions with simple but beautiful forms of language style makes Utomo's novels have high aesthetic value and are easily understood by readers.
\end{abstract}




\section{INTRODUCTION}

A long story plot in a novel is susceptible to boredom and emptiness of its meaning. It should have been anticipated by the writer with his skills in managing his or her figurative speeches to be creative and interesting. The arrangement of certain figurative speech types on a small part or a larger part of a work will provide different colors and patterns. A novel structure, with its plots, according to Fowler (in Al-Ma'ruf, 2009) is always monitored by the writer's speech manipulation.

A style or a figurative speech is typically understood as a linguistic behavior of a writer. Meanwhile, stylistics is a study about a style in a certain text. Jassin (in Nuryatin, 2010) explains figurative speech deals with diction. It selects and uses appropriate words to the intended content. It is in line with Nuryatin (2010). She states that a writer's style will appear when he has produced many literature works.

It is in line with the notion, Teeuw (2015) explains that in this modern era, stylistics frequently concerns with a rhetoric similarities but without a normative aspect. Stylistics and figurative speeches are also variously defined. However, its principle always deals with an investigation of specific and special language uses. It becomes the signature of a writer in terms of his literature perspective and so on. There is also a deviation from the typical daily language or a normal and standardized language. Based on the theory, it could be understood that the style analysis is actually a linguistic review. It is used as a medium to investigate a literature work because it is a main medium to deliver a message.

One of the theories about stylistics studies is stated by Sudjiman (in Marini, 2010). It explains that a language style covers diction, sentence structure, image, rhyme, figure of speech, and dimension applied by a writer or styles that are instilled in a literature work. It is almost similar with Pradopo's statement (in Alma'ruf, 2010:21). He states that language styles consisting of (1) intonation, (2) sound, (3) word, (4) sentence, and (5) discourse. This argument tends to be a more linguistic study. A literature stylistics does not only assess language through language but also from its covering context or the whole read or studied story.

Aminudin (2009) explains that linguistics analysis in a novel is included as stylistics study. It consists of words, punctuations, figures, and other signs that could not be analogized as words. Such stylistics studies are presented directly in a literature work. Shiley (in Supriyanto, 2014) explains that an investigation of figurative language (style) consisting of seven main elements. The elements are (1) typed-based styles such as the writer's styles, (2) mass-based styles, (3) language-based style, (4) subject-based style, (5) geographical location-based style, (6) audience-based style such as a popular style, and (7) objective-based style such as humors.

Studies concerning with figurative language has a purpose to find out how a language is used by Utomo to represent his notion in a story. It is in line with Yono and Mulyani (2017). They explain that language in a novel will reflect a writer's style because there will be his characteristics. The characteristics could be seen in the selection and implementation of the figurative language to express his ideas, notions, and imaginations. It is in line with the statement, Tarigan (1985) states that figurative language, such as figure of speech, could be used by readers or writers to explain their notions. Therefore, figure of speech could make a literature work to be more interesting and alive (Hidyat and Supriyanto, 2017).

Based on several experts, it could be concluded that a stylistics study of a literature work consisting of (1) diction, (2) sentence, (3) discourse, (4) figurative language, and (5) image. Those stylistics elements are the most frequently found in a literature work specifically a novel. Dealing with the grouping of figurative language, this research discusses only the figurative language since figurative language is closely related to a writer's style identity.

Abrams (in Supriyanto, 2014) groups figure of speech and rhetoric meant into figurative language. Figurative language consists 
of trope and rhetorical figures. Trope is defined as the use of figurative speech by the writer. Meanwhile, rhetorical figure tends to refer on the use of words and word structures of a literature work.

The explanation of figurative speech is in line with Keraf's argument (2010) as follows. The first categorization is the sentence-based figurative language. It consists of climax, anticlimax, parallelism, anti-thesis, and repetition.The second categorization is the meaning direction-based figurative language such as rhetorical and allusive language. Then, the rhetorical figurative languages are grouped into aliteration, chiasmus, elipsis, euphism, litotes, paradox, hyperbole, and so on. The allusive language is grouped into simile, metaphor, personification, and various figurative speeches.

In addition to figurative language, this research also studied the functions of figurative language in S. Praseto Utomo's novels. The novels are such as Tangis Rembulan di Hutan Berkabut which is then labelled TR, Cermin Jiwa (CJ), and Tarian Dua Wajah (TD). Perrine (in Waluyo, 1987) explains that figurative language is seen more effective to state what is meant by the poets. The statement is strengthened by Pradopo (1999). He states that the existence of figure of speech could make a literature work attractive and creates clarify of an imagination description.

Furthermore, Nurgiyantoro (2010) states that the use of allusive language or figure of speech to trigger impression and certain atmosphere, senses of responses and beautification of utterances. It means they support the aesthetic objectives of a literature work. The other functions, as stated by Kridalaksana (2009), are allusive language or figure of rhetoric or rhetorical figure as meant to broaden word or a group of words' meanings to gain certain effects. It function to compare and associate two matters. It is in line with the statement, Inayati and Nuryatin (2016) also state that allusive language could represent a symbol and meaning of a literature work. Thus, through figurative language, a writer could express the intended notion.

Based on the explanations, it could be concluded that figurative language has several functions such as a) to provide description and conceptual concretization, b) to improve the impression or certain atmosphere, c) to shorten the utterances or writing, and (d) to describe the characteristics' feelings. It is strengthened by a study from Nafiyah and Mardikantoro (2016). The research dealt with characters' analysis in a literature work. It found that through characters and characterizations, a writer could express his notion through figurative language in the novel.

Besides those functions, figurative language could also be used as learning material at school. Kusnida and Mulyani (2015) state that a literature work-based learning plan, such as short story or novel, should be properly considered. It includes in selecting the media and learning materials. The utilization values for the learners are importantly considered. It is in line with the statement. Through stylistics study, it could be found the novel reliability that is not in the learners' books or teachers' books as the complementary learning materials through the linguistics aspects. It is based on the quantity and novel excerpt quantity in the students' reading book that is found minimum. The statement is in line with Khusnin's observation (2012). There was still a teacher teaching the Indonesian language course, especially dealing with literature work, only focused on books in the course syllabus. In fact, when it is furthermost studied, the use of books at school had various limitations. These sources of the limitations were from novel varieties. The quoted novels stated in the learning books have been very popular so they could facilitate the learners by accessing the analysis from the Internet. It made the literature appreciation learning process does not properly touch the learners. The learners preferred a broader opportunity to take the shortcut.

Based on the explanations, this research aims to (1) find out and describe the figurative language realizations in Utomo's novels, (2) find out and describe the function of the figurative 
language in Utomo's novels, (3) explain the development of the figurative language utilization in Utomo's novels, and (4) use the figurative language in Utomo's novels as learning materials at schools.

\section{METHOD}

The applied method in this research is analytic descriptive method. It functions to describe and provide understandings about facts in a research object (Ratna, 2012). Meanwhile, the approach of the research is stylistics approach. This research put the data as the cause of triggering the researchers' perspectives toward forms and functions of figurative language in Utomo's novels.

\section{RESULTS AND DISCUSSION}

The Formations and Functions of Figurative Speeches in Novels Written by Prasetyo Utomo

After being analyzed, 121 metaphors were found in Tangis Rembulan in Hutan Berkabut (TR), 41 metaphors in Cermin Jiwa novel (CJ), and 115 metaphors in Tarian Dua Wajah novel (TD). The other most frequent figurative speech was simile. 43 similes were found in TR. 84 similes were found in CJ. 67 similes were found in TD. Hyperbole is also the most frequent figure of speech. 57 hyperboles were found in TR. 30 hyperboles were found in CJ. 37 hyperboles were found in TD. Then, personification also dominated those three Utomo's novels. 58 personifications were found in TR, 26 in CJ and 26 in TD. The last figure of speech was Pars pro toto figure of speech. 11 pars pro toto were found in TR, 84 in $\mathrm{CJ}$, and 31 in TD.

Here are the forms of the novels' figurative language as presented in the Table. They are arranged based on the number of the figurative speech for each part of the novels.
Table 1. The Number of Figurative Language in Tangis Rembulan di Hutan Berkabut Novel

\begin{tabular}{llllll}
\hline & Sim & Meta & Per & Hip & Toto \\
\hline 1 & 5 & 14 & 10 & 13 & 1 \\
2 & 3 & 14 & 8 & 7 & 5 \\
3 & 3 & 27 & 7 & 6 & - \\
4 & 5 & 27 & 6 & 11 & 1 \\
5 & 8 & 23 & 6 & 10 & 1 \\
6 & 9 & 11 & 8 & 4 & 1 \\
7 & 7 & 3 & 11 & 5 & 2 \\
8 & 3 & 2 & 2 & 1 & - \\
\hline T2 & 43 & 121 & 58 & 57 & 11 \\
\hline
\end{tabular}

Table 2. The Numbers of the Figurative Speech in Cermin Jiwa Novel

\begin{tabular}{llllll}
\hline & Sim & Meta & Per & Hip & Toto \\
\hline 1 & 3 & 9 & 2 & 3 & 1 \\
2 & 2 & 7 & - & 5 & 1 \\
3 & 5 & 1 & - & - & - \\
4 & 2 & 7 & - & 2 & 1 \\
5 & 4 & 15 & - & 3 & 1 \\
6 & 5 & 8 & 2 & 3 & 4 \\
7 & 5 & 8 & 3 & 1 & 2 \\
8 & 2 & 3 & - & 2 & 1 \\
9 & 8 & 8 & 4 & - & 1 \\
10 & 5 & 5 & 2 & 1 & - \\
11 & 4 & 6 & 2 & - & - \\
12 & - & 3 & - & - & - \\
13 & 5 & 9 & 1 & - & - \\
14 & - & 3 & 7 & 1 & 1 \\
15 & 3 & 7 & - & 1 & - \\
16 & 2 & 3 & - & - & - \\
17 & 1 & 1 & 1 & 1 & - \\
18 & 4 & 2 & 3 & - & 6 \\
19 & 2 & 3 & 2 & - & 1 \\
20 & 3 & 4 & 1 & - & - \\
21 & 2 & 6 & 2 & - & - \\
22 & 1 & 7 & 2 & 2 & - \\
23 & 2 & 9 & 1 & 1 & - \\
24 & 2 & 4 & 1 & - & 2 \\
25 & 9 & 14 & - & 2 & 2 \\
26 & 3 & 5 & 2 & 2 & - \\
\hline $\mathrm{T} 2$ & 84 & 41 & 26 & 30 & 24 \\
\hline & & & & &
\end{tabular}


Table 3. The Numbers of the Figurative Speech in Novel Tarian Dua Wajah

\begin{tabular}{llllll}
\hline & Hip & Sim & Meta & Per & Toto \\
\hline 1 & 2 & 5 & 10 & 4 & 3 \\
2 & 1 & 6 & 2 & 2 & - \\
3 & 1 & 4 & 1 & - & - \\
4 & 1 & 5 & 5 & 3 & 2 \\
5 & 2 & 2 & 5 & - & 3 \\
6 & 5 & 6 & 6 & 1 & 1 \\
7 & - & - & 2 & - & 1 \\
8 & - & 2 & 4 & 2 & 4 \\
9 & 6 & 1 & 6 & 3 & - \\
10 & 3 & 2 & 6 & 4 & 3 \\
11 & 1 & - & 9 & - & 3 \\
12 & 2 & 4 & 2 & - & 4 \\
13 & 1 & 6 & 5 & - & - \\
14 & 1 & 4 & 4 & - & - \\
15 & 1 & 1 & 4 & 1 & 1 \\
16 & - & 1 & 1 & - & - \\
17 & 1 & 2 & 5 & - & 1 \\
18 & 1 & 4 & 4 & 3 & 2 \\
19 & 2 & - & 3 & - & 1 \\
20 & 2 & 6 & 8 & 3 & 1 \\
21 & - & - & 1 & - & - \\
22 & 2 & 1 & 10 & - & 1 \\
23 & - & 1 & 3 & - & - \\
24 & 2 & 2 & 7 & - & - \\
25 & - & - & 2 & - & - \\
\hline T2 & 37 & 67 & 115 & 26 & 31 \\
\hline & & & & & \\
\hline
\end{tabular}

\section{The Figurative Language of S. Prasetyo Utomo's Novels}

In addition to figurative language, this research also studied the functions of figurative language in S. Praseto Utomo's novels. Here are the sample analysis of the figurative language functions in the novels. There were several functions of metaphors in the novels. They were (a) language function of metaphor to clarify the descriptions or concretization of concepts, (b) invoking or improving the impressions toward certain atmosphere, (c) shortening the utterances, and (d) describing the characters' feelings.

One of the reasons of figurative speech in the literature review is to facilitate the information gain for the readers. It is also common when a writer wants to express something complicated, he choses figurative speech as a technique to facilitate his notion delivery.

Angin malam meniupkan - bau maut. (TR: 21)

The phrase bau maut is used by Utomo to describe the atmosphere at that evening. It seems like telling there will be a bloodshed. A strange and uncommon atmosphere is on going. Such asbtract concept could be delivered easily for readers by using the phrase of bau mulut. It is a metaphor.

The function of such metaphor is to invoke or improve a certain atmosphere of an impression. Figurative speech also functions to invoke or improve impression toward a certain atmosphere. It also includes Utomo's novels. Here are the analysis of the figurative speech functions.

Nada kecemasan menggayuti mereka. (TR: 16)

The phrase, nada kecemasan, provides a clear description about a certain engaged situation by the people around the main character. This metaphor phrases invokes impression for the readers toward a certain anxiety felt by the characters in Tangis Rembulan di Hutan Berkabut novel.

The direct comparison of the metaphor is appropriately used to shorten the utterance. It is proven with several findings on the data.

\section{Rupanya Mas Gun menangkap \\ kegelisahanku. (TR: 19)}

In the excerpt, the phrase menagkpak kegelisahanku, means that Mas Gun could understand and share responses toward the main character in the novel. The word menangkap or catch could shorten the explanation about Mas Gun's action.

The next function of the metaphor was to describe the characters' feelings. Here is an evidence of the function in Tangis Rembulan di Hutan Kabut.

Di dalam rumah tinggal perempuan tua yang tersekap kesepian. (TR: 16)

The excerpt describe the condition of the character's wife, Lik Sukro. The phrase tersekap kesepian describes the character's feeling. That loneliness or kesepian is caused by her husband'a 
madness so she is left alone at home. The analysis becomes a strong reason for the metaphor in the excerpt. It functions to describe the characters.

In addition to metaphor figurative speech function, there are also simile figurative speech functions. They are: (A) the function of simile figurative speech is to describe or concretize a concept, (b) it is to trigger or improve impression of a certain atmosphere, (c) it is to shorten an utterance, and (d) it is to describe the characters' feelings.

The figurative speech of a simile is done by comparing and it is well used to clarify certain description. It is proven by its high frequent findings.

Lik Sukro bagai pralambang. Gerakgeriknya bagai isyarat bagi orang-orang untuk melihat peristiwa yang bakal menimpa. (TR: 16)

The word paralabang is understood with broader meaning.as the initial sign of an event. By using words, the abstract concept in the writer's mind could be expressed clearer and more understandable.

Simile in the novels also functioned to improve the impressions of a certain atmosphere. The triggered atmospheres were also varied. They are such as sad, stressful, happy, or tragic. Here are the simile functions to improve the impression of a certain atmosphere.

\section{Bicara dan tertawa sendiri seperti orang} tak waras." (TR: 16)

Any simile that compares indirectly the character's behaviors with mental disorder. The word, seperti, in the excerpt, connects two compared things. From simile, the readers cold feel the impressions of the characters' atmospheres around Lik Sukro, the character.

The figurative language function of a simile is to shorten utterances. One of the ways to shorten an utterance is by using simile. It is a technique to shorten an utterance because the writer does not need to describe something completely if he could find an equivalent to what he wants to deliver.
Di hadapanku terlihat samar-samar tubuh Sekar bergelung di pangkuan juragan, terlena macam seekor kucing. 65

Simile, in the excerpt, compares a character, Sekar, with a cat. The use of such indirect comparison functions to shorten the writer's utterances because he does not need to describt the character in detail.

Simile also functions to describe the characters' feelings. The analysis on simile found that simele functioned to describe the characters' feelings. Here is the example.

$$
\begin{aligned}
& \text { Dia seperti orang yang terganggu } \\
& \text { ingatannya. (TR: } 11 \text { ) }
\end{aligned}
$$

The data is the example of simile. It functions to describe the characters' feelings. The main reason of the function is the existence of comparison describing the natures of the characters. In fact, in this case, what is being compared is the character's behavior with any disorder natures found in people with mental health disorder.

The next is hyperbole's functions. There are several functions of hyperbole. They are (a) to provide clear description, (b) to trigger and improve impression of a certain atmosphere, (c) to shorten an utterance, and (d) to describe the characters' feelings.

Hyperbole speeches were found many in the novel. The quantity of this figurative speech influenced those four functions of language styles.

\section{Memandangiku dengan mata goncang.}

The functions of hyperbole is to represent the writer's concept about how he sees the characters. Such language could represent the doubt of the character. (B) hyperbole has function to invoke or improve a certain atmosphere of an impression. An impression toward a certain atmosphere will be easy to get with the assistance of hyperbole. It is caused by exaggerated effects of the figurative speech. Sad, happy, and sorrow impressions could be delivered exaggeratedly. Here are some analysis of hyperbole found in Utomo's novels. 


\section{Tergelar kegersangan yang rapuh dan sunyi.}

(TR: 9)

When reading the excerpt, the effect appears in our mind is a quite changing atmosphere. That arid atmosphere due to fallen tree is considered exaggerating when it is added by a word rapuh dan sunyi (fragile and quiet). However, the hyperbole in the data could be used as a meant to invoke impression of a mood and reality in a village simultaneously.

The function of hyperbole is to shorten utterances. The analysis of hyperbole in Tangis Rembulan di Hutan Berkabut found 10 hyperboles with a function to shorten the utterances, from 57 hyperboles. Here are the examples of the hyperbole analysis results in Tangis Rembulan di Hutan Berkabut novel.

\section{Tanah terbuka sepanjang pandangan}

mata setelah hutan karet ditebang. (TR:

9)

The excerpt contains a hyperbole because it triggers an effect to imagine a very large place until the end of a reader sees. The phrase, sepanjang pandangan mata (as far as we see) could be actually delivered by an utterance of a large and wide field sized one thousand meter or other description.

The character's feeling is an important matter to be delivered. It is due to feeling is a constructive element that influences the story plot. Hyperbole is a medium to deliver the character's feeling in the novel. Here are the explanations about the function, to describe the character's feeling, in Utomo's novel.

Membebaskan diri dari perangkap

istri Lik Sukro. (TR: 13)

The use of a word terperangkap, or trapped, provides impression that the character is feeling inconvenience with the conditions he experiences. The character is not really happy to tell with Lik Sukro's wife. From the explanation, it could be concluded that hyperbole is an excerpt with a function to describe characters' feelings.

\section{CONCLUSION}

A literature work exists as the result of creative thinking process of the writer about society's culture and his word. When a writer writes more, his figurative language could be clearly seen. One of the constructive elements of figurative language consists of sentence strategy, rhetorical language, and allusive language. What were investigated from Utomo's novels were the forms and functions of the figurative language. Those novels were Tangis Rembulan di Hutan Berkabut, Cermin Jiwa, and Tarian Dua Wajah. Here are the investigation conclusions of the novels.

The analysis of the novels found various figurative language. The most frequent figurative speeches were metaphor with 277 , simile with 194, and hyperbole with 124. The figurative speeches consisted of words, phrases, and clauses. Based on the explanations, it could be seen that Utomo's style was simple and full of figurative language. Utomo is considered a genius to use the language in writing novels although he applies many styles but his works were still readable with simple and understandable language.

The applied style also meets the requirements of various figurative speech functions. Based on the analysis, four functions of figurative speeches were found. They were to invoke or improve the impression upon a certain atmosphere, to shorten the utterances or writing, and to describe the characters' feelings.

\section{REFERENCE}

Alimatussa'diyah dan Agus Nuryatin. (2017). Inferioritas Tokoh Perempuan dalam Novel Bumi Cinta Karya Habiburrahman El Shirazy. Artikel. Seloka 6 (1) (2017) : 15 -24 .

Al-Ma'ruf, Ali Imron. 2009. "Kajian Stilistika Aspek Bahasa Figuratif Novel Ronggeng Dukuh Paruk Karya Ahmad Tohari". Kajian Linguistik dan Sastra, Vol. 21, No. 1, Juni 2009: 67-80. 
Al-Ma'ruf, Ali Imron. 2010. Kajian Stilistika Perspektif Kritik Holistik. Surakarta: UPT Penerbitan dan Percetakan UNS (UNS Press).

Aminudin. (2009). Pengantar Apresiasi Karya Sastra. Sinar Baru Agresindo: Bandung.

Hidayat, Aryo Dwi dan Teguh Supriyanto. (2017). Paradoks dan Hiperbola dalam Kumpulan Cerita Koala Kumal Karya Raditya Dika. Seloka: Jurnal Pendidikan Bahasa dan Sastra Indonesia, 6 (1).

Inayati, Tatik dan Agus Nuryatin. (2016). "Simbol dan Makna pada Puisi Menolak Korupsi Karya Penyair Indonesia. Seloka: Jurnal Pendidikan Bahasa dan Sastra Indonesia, 5 (2): 163-171.

Keraf, Gorys. (2010). Diksi dan Gaya Bahasa. PT Gramedia: Jakarta.

Khusnin, Mukhamad. (2012). "Gaya Bahasa Novel Ayat-Ayat Cinta Karya Habiburrahman El Shirazy dan Implementasinya terhadap Pengajaran Sastra Di SMA". Artikel. Seloka: Jurnal Pendidikan Bahasa dan Sastra Indonesia. Seloka: Jurnal Pendidikan Bahasa dan Sastra, 1 (1): 45-53.

Kridalaksana, Harimurti. (2009). Kamus Linguistik Edisi Keempat. PT Gramedia: Jakarta.

Kusnida, Faris dan Mimi Mulyani. (2015). "Keefektifan Penggunaan Media Audiovisual dan Media Komik Strip dalam Pembelajaran Menulis Cerpen yang Bermuatan Nilai-Nilai Karakter Berdasarkan Gaya Belajar". Seloka: Jurnal Bahasa dan Sastra Indonesia, 4 (2): 111-117.

Nafiyah, Khifdziyatun dan Hari Bakti Mardikantoro. (2016). "Permasalahan Perempuan dalam Kumpulan Cerpen
Malam Sepasang Lampion Karya Triyanto Triwikromo". Seloka: Jurnal Pendidikan Bahasa dan Sastra Indonesia, 5 (1): 21-29.

Nurgiyantoro, Burhan. (2010). Teori Pengkajian Fiksi. Yogyakarta: Gajah Mada University Press. Waluyo,

Nuryatin, Agus. (2010). Mengabadikan Pengalaman dalam Cerpen: 7 Langkah Pembelajaran Menulis Cerpen. Semarang: Yayasan Adhigama.

Pradopo, Rachmat Djoko. (1999). Pengkajian Puisi Analisis Strata Norma dan Analisis Struktural dan Semiotik. Yogyakarta: Gadjah Mada University Press.

Prastowo, Andi. (2012). Panduan Kreatif Membuat Bahan Ajar Inovatif. Yogyakarta: Diva Press.

Ratna, Nyoman Kutha. (2009). Estetika Sastra dan Budaya. Yogyakarta: Pustaka Pelajar.

Sudjana, Nana. (2013). Dasar-Dasar Proses Belajar-Mengajar. Bandung: Sinar Baru Algensindo.

Supriyanto, Teguh. (2014). Kajian Stilistika dalam Prosa. Elmatera Publishing: Yogyakarta.

Utomo, S. Prasetyo. (2008). Tangis Rembulan di Hutan Berkabut. Semarang: $\mathrm{H}_{2} \mathrm{O}$ Publishing.

Utomo, S. Prasetyo. (2016). Tarian Dua Wajah. Jakarta: PT. Pustaka Alvabet.

Utomo, S. Prasetyo. (2017). Cermin Jiwa. Jakarta: PT. Pustaka Alvabet.

Waluyo, Herman J. (1987). Teori dan Apresiasi Puisi. Jakarta: Erlangga.

Yono, Robert Rizky dan Mimi Mulyani. (2017). Majas dan Citraan dalam Novel Kerling Si Janda Karya Taufiqurrahman AlAzizy. Seloka: Jurnal Pendidikan Bahasa dan Sastra Indonesia, 6

(2). 